\title{
TRPM6 Gene
}

National Cancer Institute

\section{Source}

National Cancer Institute. TRPM6 Gene. NCI Thesaurus. Code C147082.

This gene plays a role in both magnesium ion transport and protein phosphorylation. 